\title{
Is Tourism a Key Factor for Economic Growth? Fresh Evidence from South Europe Using Panel Cointegration and PVAR Analyses
}

\author{
IOANNIS KOSTAKIS
}

Received: 11.10.2020; Revised: 05.11.2020; Accepted: 09.11.2020

\begin{abstract}
This paper brings fresh empirical evidence on the relationship between tourism and economic growth for five South European countries over the period 2000Q1-2018Q4 within a multivariate framework. PVAR and panel cointegration analyses are employed to infer the causal relationship between tourism and economic growth. Heterogeneous panel cointegration test reveals a long-run relationship between real GDP, labour force, gross fixed capital formation and tourism. Granger causality validates the bidirectional and unidirectional causal relationship between tourism, labour and economic growth and physical capital and economic growth, respectively. Simultaneously, impulse-response functions of PVAR model highlight the fact that short-run innovations might have a smaller impact on economic growth against a permanent long-run augmentation of these variables. Our findings might leave ample room for government policies to stimulate strategies for higher economic growth.
\end{abstract}

JEL codes: C23, L83, Z32

Keywords: Tourism, Economic growth, PVAR model, Panel impulse response functions, Panel cointegration

\section{Introduction}

With prompt population growth and rapid globalization, the role of tourism as an important contributor to economic growth has gradually gained the attention of academics and policymakers. It constitutes a big part of the economic growth (Matias et al., 2011; Morakabati et al., 2012), alleviating the pressure on countries' balance of payments (Paci \& Marrocu, 2014) and creating multiplier effects on several sectors as well (Cortes-Jimenez \& Pulina, 2010). This is based on the fact that tourism is a complementary service with other economic activities that boost income and contribute to job creation (Pulido-Fernández \& Cárdenas-García, 2020), poverty reduction (Khan et al., 2020), improvements in the standard of living (Muslija et al., 2017), and stimulation of foreign exchange earnings.

However, it is of interest to distinguish the priorities that governments have to take into account before implementing each policy. For instance, Fahimi et al. (2018) indicate that the trend of increasing government spending to several campaigns of marketing towards travel

a Department of Home Economics and Ecology, Harokopio University of Athens, Greece. email: ikostakis@hua.gr (D) https://orcid.org/0000-0002-3507-5737 
and tourism raises researchers' curiosity to examine if the prioritization of tourism sector should be the best beneficial strategy for economic growth. It is also known that investments on industry or on services have a different impact on economic development, by changing several aspects of social life such as the environmental quality (Kostakis et al., 2017), the level of well-being of the resident population (Pulido Fernández \& Sánchez Rivero, 2010) or the structure of the employment within a country.

Regarding tourism sector, in recent years, many empirical studies ${ }^{1}$ have addressed the issue of the so-called tourism-led growth (TLG) hypothesis using several estimation methodologies based mainly on time series data (Oh, 2005; Chen \& Chiou-Weib, 2009; Payne \& Mervar, 2010; Schubert et al., 2011; Adnan Hye \& Ali Khan, 2013; Amir et al., 2015; Tang \& Tan, 2015; Andraz \& Rodrigues, 2016; Banerjee et al., 2016; Kumar \& Stauvermann, 2016) and panel data (Dritsakis, 2004; Eugenio-Martín et al., 2004; Kostakis \& Theodoropoulou, 2017; C.-C. Lee \& Chang, 2008; Soukiazis \& Proenca, 2008; Holzner, 2011; Apergis \& Payne, 2012; J. W. Lee \& Brahmasrene, 2013; Paci \& Marrocu, 2014; Tuğcu, 2014; Bojanic \& Lo, 2016; Liang \& Hui, 2016; De Vita \& Kyaw, 2016; Zhang \& Gao, 2016; Muslija et al., 2017; Antonakakis et al., 2019; Ballı et al., 2019; Gao et al., 2019; Eyüboğlu \& Eyüboğlu, 2020). The main question in all these studies is whether tourism acts as a significant driver for economic growth. Nevertheless, even if the results with respect to the relationship between tourism and economic growth are highly controversial in many cases, the majority of the research has concluded that tourism is a key factor for economic growth.

World Travel and Tourism Council (2020) highlights the significant role of tourism in the world economic performance. More specifically, South Europe, that has been chosen in our analysis, is considered as a prominent tourist destination. Over the last decades, tourist arrivals in France, Greece, Italy, Portugal and Spain account for more than $50 \%$ of the total $\mathrm{EU}$ arrivals (Eurostat). Based on the most recent data of $\mathrm{WTTC}^{2}$, tourism contributes $13.0 \%$ and $14.3 \%$ to GDP of Italy and Spain, respectively. Similarly, the total contribution of travel and tourism to GDP is more than 20\% in Greece at a growth rate of $12.1 \%$ in 2019. In France, more than 9\% of total employment is in the tourism sector, which is expected to contribute 3.5 million new jobs by 2029. In Portugal, the total contribution of travel and tourism to GDP is around $16 \%$ while the growth rate of this sector was more than $4 \%$ in 2019. However, it is known that tourism is a highly volatile variable. A crisis such as the financial crisis in 2008 or the current pandemic crisis of COVID-19 might overturn these expectations. For example, several international institutes already highlight that the economies in which tourism is the main factor of economic growth have been hit more severely than other countries (European Commission, 2020).

Thus, the initial aim of this study is to designate if the relationship between tourism and economic growth is unidirectional or bidirectional given that, tourism can be an important tool for economic growth. It is known that tourism development refers to the improvement of infrastructure and services in a tourist destination that also contributes to the increase in tourists' arrivals (Pulido-Fernández \& Cárdenas-García, 2020). However, the main question is if the outspread of tourism activity can significantly improve the citizens' level of standards of living in countries where tourism occurs. In other words, this study endeavours to

\footnotetext{
${ }^{1}$ For a more recent literature survey on the relationship between tourism and economic growth, please see Brida et al. (2016) and Nunkoo et al. (2020), which provides a meta-analysis.

2 https://wttcweb.on. uat.co/Research/Economic-Impact
} 
answer if tourism investments should be one of the main priorities of governments and if yes, in which way it can be successfully done. For this purpose, firstly, the present study focuses on the Mediterranean areas that are considered among the most competitive tourism destinations in Europe. Secondly, we investigate the tourism-growth hypothesis using PVAR and panel cointegration analyses, assessing this relationship in a short and long-run horizon simultaneously. Empirical results from a heterogeneous panel cointegration test reveal a long-run relationship between real GDP, labour force, gross fixed capital formation, and tourism with the respective coefficients, showing a statistically significant and positive sign. The bidirectional/feedback hypothesis is confirmed with respect to tourism. Furthermore, the impulse-responses of PVAR model confirm these results but highlight that this relationship mainly holds in the long-run.

We feel that the empirical results and our approach might be useful for the design of a new government agenda that can stimulate economic growth of the Southern European economies. However, the present empirical results underline that governments and policymakers should also invest in more long-run and stable strategies. Tourism could be considered as a non-stable sector, and this can be easily seen nowadays due to the COVID19 pandemic crisis. In addition, more and more countries become more tourism competitive destinations decreasing the profits and the benefits of the tourism sector within economies. On the other hand, empirical findings confirm that a strong capital and labour force sector could be also strong economic growth leader-sectors. In other words, in our case, even if tourism has been confirmed as an important determinant of economic performance, it seems that Mediterranean countries could also shift their structure of investments to other sectors succeeding an economic convergence from other northern and richer economies.

The rest of the paper is organised as follows. Section 2 presents the data for the particular countries of the Mediterranean area. Section 3 presents the empirical methodology and results. Lastly, Section 4 provides conclusions, as well as policy implications derived from the empirical findings.

2 Data Characteristics for the Sample of the South European Economies: France, Greece, Italy, Portugal, and Spain

The present study uses quarterly data (obtained from Eurostat) from a panel of five Mediterranean countries - France, Greece, Italy, Portugal, and Spain - on their GDP, labour

Table 1: Summary Statistics

\begin{tabular}{llcccc}
\hline Countries & Statistics & GDP & Labour & Capital & Tourism \\
\hline \multirow{2}{*}{ France } & Mean & $8,070.90$ & 0.393 & 1,793 & 421 \\
& St. dev. & 0.28 & 0.01 & 0.08 & 14.1 \\
Greece & Mean & $4,592.30$ & 0.368 & 0.832 & 357 \\
& St. dev. & 0.49 & 0.03 & 0.3 & 68.51 \\
\multirow{2}{*}{ Italy } & Mean & $7,205.70$ & 0.372 & 1,417 & 332 \\
& St. dev. & 0.28 & 0.01 & 0.18 & 30.1 \\
Portugal & Mean & $4,367.70$ & 0.439 & 0.853 & 317 \\
& St. dev. & 0.14 & 0.02 & 0.15 & 85.32 \\
\multirow{2}{*}{ Spain } & Mean & $5,809.20$ & 0.405 & 1,241 & 446 \\
& St. dev. & 0.24 & 0.04 & 0.2 & 61.47 \\
\hline
\end{tabular}

Sources: Eurostat. Own calculations.

Note: Per capita GDP and physical capital in thousands Euros, Labour is percent of total population, and Tourism in persons. 
force, gross fixed capital formation, and tourist arrivals over the period 2000Q1-2018Q4. For the purposes of comparison, GDP, capital and tourism presented in Table 1, which are seasonally adjusted and converted into per capita values, while labour is presented as a percent of the total population.

Quarterly per capita GDP value ranges from 4,367 euro in Portugal to 8,070 euro in France. The countries of the Iberian Peninsula present the highest levels of labour percent (0.43 for Portugal and 0.41 for Spain), while Greece presents the lowest level. As far as physical capital is concerned, France, Italy, and Spain have higher values of per capita investment, distantly followed by Greece and Portugal. As for tourist arrivals, Spain and France have more than 400 tourists per capita, while Greece receives 357 tourists, Italy 332, and Portugal 317, on average. In terms of tourists, Figure 1 demonstrates the variation of per capita tourists over a quarterly time period for each country of the sample.
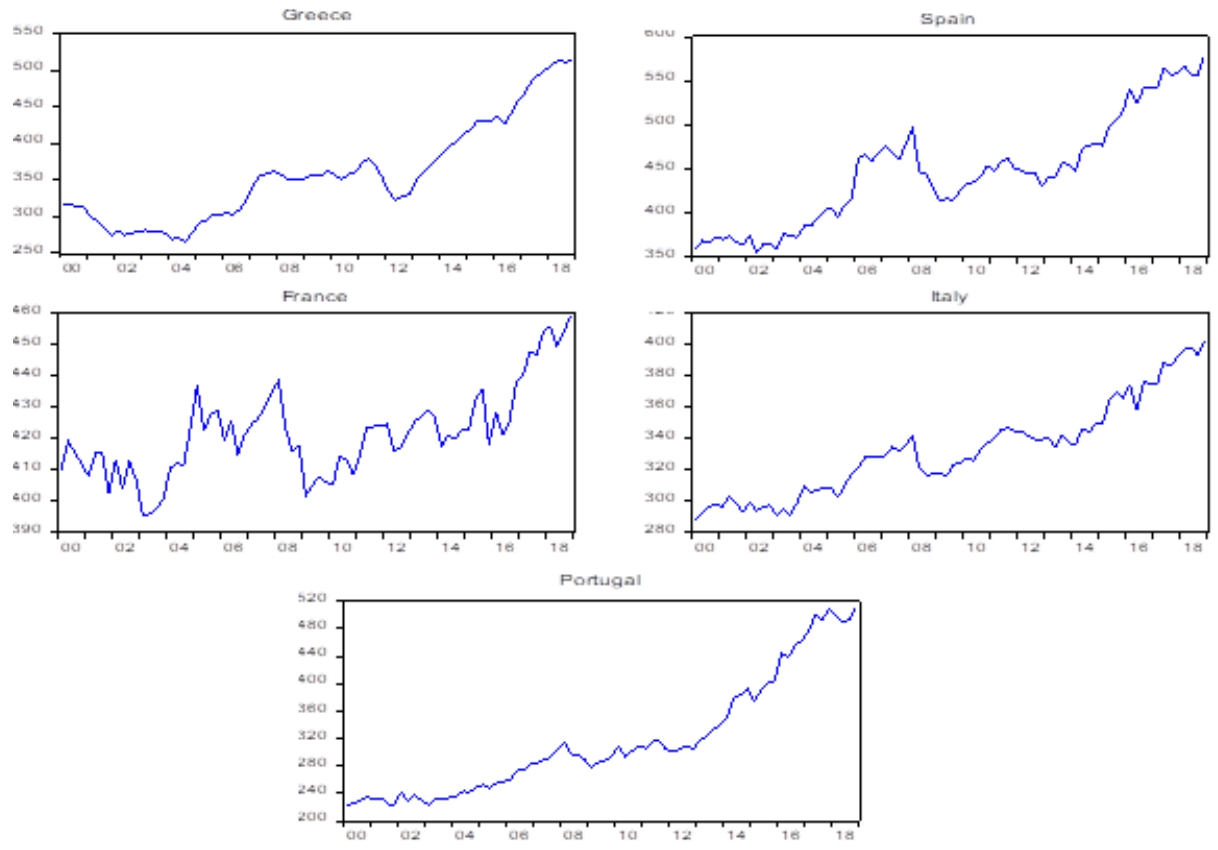

Figure 1: Per capita Tourist Arrivals in the Mediterranean Countries, 2000Q1-2018Q4

Clearly, around the period of economic turbulence due to the global financial crisis, there is a negative trend within economies, highlighting the detrimental role of a crisis on tourism. However, in general, there is an obvious, increasing trend of the number of per capita tourists, confirming the increasing importance of tourism on the economies of South Europe.

\section{Methodology and Results}

\subsection{Panel Cointegration Analysis}

In the case of macro panel data analysis, a variety of panel unit root tests are available, such as those of Breitung (2001), Hadri (2000), Choi (2001), Levin et al. (2002), and Im et 
al. (2003). Table 2 presents the unit root test following the procedure of Im et al., Breigung test, Levin et al. test and ADF-Fisher test. As shown, the majority of the tests show that series, expressed in natural logarithm, are integrated of order one I(1).

Table 2: Panel Unit Root Test Results

\begin{tabular}{llcccccccc}
\hline Test & Variable & GDP & $\Delta$ GDP & Labour & $\Delta$ Labour & Capital & $\Delta$ Capital & Tourism & $\Delta$ Tourism \\
\hline \multirow{2}{*}{ Im et al. } & $\mathrm{C}$ & 0.834 & $-4.259^{* *}$ & -1.206 & $-3.568^{* *}$ & 1.06 & $-3.869^{* *}$ & 3.945 & $-6.569^{* *}$ \\
& $\mathrm{C} \& \mathrm{~T}$ & 0.778 & $-8.807^{* *}$ & 0.426 & $-2.067^{* *}$ & 1.288 & $-2.549^{* *}$ & 0.119 & $-5.927^{* *}$ \\
\hline \multirow{2}{*}{ Breigutg } & $\mathrm{C} \& \mathrm{~T}$ & -1.541 & $-3.771^{* *}$ & -1.413 & $-2.103^{* *}$ & -0.095 & $-3.326^{* *}$ & 0.301 & $-6.473^{* *}$ \\
\hline \multirow{2}{*}{ Levin et al. } & $\mathrm{C}$ & 0.299 & $-2.180^{* *}$ & $-1.698^{* *}$ & -0.045 & -0.057 & 1.58 & 2.815 & 3.482 \\
& $\mathrm{C} \& \mathrm{~T}$ & 0.188 & $-1.532^{* *}$ & -0.794 & 0.532 & 0.355 & $2.787^{* *}$ & 0.312 & 5.689 \\
\hline \multirow{2}{*}{$\mathrm{ADF}-\mathrm{Fisher}$} & $\mathrm{C}$ & 4.192 & $38.452^{* *}$ & 13.017 & $33.364^{* *}$ & 4.654 & $33.328^{* *}$ & 0.726 & $63.991^{* *}$ \\
& $\mathrm{C} \& \mathrm{~T}$ & 4.549 & $25.330^{* *}$ & 6.597 & $21.649^{* *}$ & 4.42 & $21.790^{* *}$ & 8.292 & $50.908^{* *}$ \\
\hline
\end{tabular}

Note: All variables (GDP, Labour, Capital and Tourism) are expressed into its natural logarithms. The Greek letter $\Delta$ denotes the first difference of the variables. C denotes constant and C\&T denote constant and trend. Null hypothesis is that all series have a unit root. Critical values are upon request. ** denotes statistical significance at $5 \%$.

Thereafter, the heterogeneous panel cointegration test of Pedroni $(1999,2004)$ allows for cross-section interdependence with different individual effects taken as follows:

$$
y_{i t}=\alpha_{i t}+\delta_{i} t+\beta_{1 i} L_{i t}+\beta_{2 i} C_{i t}+\beta_{3 i} T_{i t}+\epsilon_{i t}
$$

where $y, L, C$, and $T$ stand for GDP, labour, capital, and tourism, respectively; $i$ is the country; $t$ denotes the time period; $\alpha_{i t}$ in the country-specific effects; $\delta_{i}$ refers to the deterministic trends; $\epsilon_{i t}$ are the estimated residuals representing the deviations from the long-run relationship. As all variables are expressed in natural logarithms, the $\beta$ parameters can be interpreted as long-run elasticities. The null hypothesis of no cointegration is checked through the following unit root test $\left(\rho_{i}=1\right)$ in the estimated residuals.

$$
\epsilon_{i t}=\rho_{i} \epsilon_{i t-1}+u_{i t}
$$

Based on this equation, Pedroni proposes two sets of tests for panel cointegration: panel and group mean tests. The first tests depend on the within-dimension approach and include four statistics: panel $\rho$-statistic, panel $v$-statistic, panel PP-statistic, and panel ADF statistic. These statistics take into account common time factors and heterogeneity across units. The second set of statistics is based on the between-dimension approach and includes three statistics (group $\rho$-statistic, group PP-statistic, and group ADF statistic). All tests

\begin{tabular}{|c|c|c|c|}
\hline $\begin{array}{c}\text { Alternative hypothesis: } \\
\text { common AR coefs. } \\
\text { (within-dimension) }\end{array}$ & $\begin{array}{c}\text { Test } \\
\text { statistics }\end{array}$ & $\begin{array}{l}\text { Alternative hypothesis: } \\
\text { individual AR coefs. } \\
\text { (between-dimension) }\end{array}$ & $\begin{array}{c}\text { Test } \\
\text { statistics }\end{array}$ \\
\hline Panel $v$-Statistic & 0.59 & Group $\rho$-Statistic & $-1.467^{*}$ \\
\hline Panel $\rho$-Statistic & $-3.209^{*}$ & Group PP-Statistic & $-2.329 * *$ \\
\hline Panel PP-Statistic & $-3.508^{* *}$ & Group ADF-Statistic & -0.443 \\
\hline Panel ADF-Statistic & 0.068 & & \\
\hline Westerlund & $2.233^{* *}$ & $\begin{array}{l}\text { Kao Residual Cointegration } \\
\text { ADF Test }\end{array}$ & $-4.948 * *$ \\
\hline
\end{tabular}

Table 3: Panel Cointegration Tests 
are distributed asymptotically as standard normal. The Kao (1999) test, based on Engle \& Granger (1987) two-step (residual-based) cointegration tests, is also estimated. In addition, we apply the second-generation cointegration test of Westerlund (2007) that determines whether error correction exists for individual panel members or for the panel as a whole, and also check cointegration between non-stationary variables. The results displayed in Table 3 and suggest that there is cointegration between the assessed variables.

With the exception of panel ADF and $v$-Statistics, the remaining Pedroni panel cointegration tests reject the null hypothesis of no cointegration. Also, Kao (1999)'s residual cointegration is rejected at the $1 \%$ significance level, highlighting that all variables are cointegrated. Additionally, the Westerlund (2007) test also confirms the hypothesis of cointegration. Thereafter, the fully modified FMOLS approach for heterogeneous cointegrated panels is estimated. Table 4 reports the FMOLS findings.

Table 4: Panel FMOLS Estimates

\begin{tabular}{lrrr}
\hline FMOLS & Labour & Capital & Tourism \\
\hline Per capita & $0.338^{*}$ & $0.227^{*}$ & $0.242^{*}$ \\
GDP & -37.3 & -16.02 & -22.22 \\
& {$[0.0090]$} & {$[0.0142]$} & {$[0.0109]$} \\
\hline \multicolumn{2}{l}{$\begin{array}{l}\text { Note: t-tests are presented in parentheses and standard } \\
\text { errors in the brackets. }{ }^{*} \text { denotes significance at }\end{array}$ 5\% level. }
\end{tabular}

The results indicate a significant positive relationship between tourism and economic growth. Additionally, a significant positive impact is also found for physical capital and labour force on economic performance. However, it is worthy mentioned that the contribution of tourism factor to economic growth is lower as compared to the labour driver and almost equal to the capital driver of growth in this geographical area. More specifically, as all variables are presented in its natural logarithms, the estimates can be interpreted as long-run elasticities. As shown, the estimated coefficients are significant with a positive sign, as anticipated. The long-run elasticity of per capita GDP with respect to labour force is significantly positive; this means that a $1 \%$ increase in labour force increases per capita GDP by around $0.34 \%$. The sign of gross fixed capital formation indicates that an increase in per capita investment stock leads to an increase in growth in per capita GDP by $0.23 \%$. In addition, the long-run elasticity of per capita GDP with respect to per capita tourist arrivals is also positive; a $1 \%$ increase in per capita tourist arrivals increases per capita GDP by $0.24 \%$. Based on these findings, it is worth noting that labour has the highest impact on economic performance in South European countries in the long-run. However, this result is expected, as South Europe could be mainly characterized as a labour-led and not capital-led growth region. In general, empirical results confirm that physical capital, labour force and tourism constitute positive factors of economic growth but with a different magnitude. The focus on one factor will lead to a lower economic performance than investing in all these variables as a group within economies.

Thereafter, given that the variables of interest are cointegrated, a panel vector error correction model is estimated by performing Granger causality tests. More specifically, to infer a possible causal relationship between these variables, Engle \& Granger (1987) proposed a two-step procedure that should be undertaken. After estimating the long-run model in order to obtain the residuals, we define the lagged residuals from this equation as 
the error correction term and estimated the following dynamic error correction model.

$$
\begin{aligned}
Y_{i t}=a_{i j}+\sum_{k=1}^{q} \beta_{i j i k} \Delta Y_{i t-k}+\sum_{k=1}^{q} \beta_{i j i k} \Delta L_{i t-k} & +\sum_{k=1}^{q} \beta_{i j i k} \Delta C_{i t-k} \\
& +\sum_{k=1}^{q} \beta_{i j i k} \Delta T_{i t-k}+\lambda_{i i} \epsilon_{i t-1}+u_{1 i t}
\end{aligned}
$$

where $\Delta$ is the first-difference operator; $q$ is the lag length set as one based on the likelihood ratio test, and $u$ is the serially uncorrelated error term of the equations. ${ }^{3}$ Table 5 reports the error correction model estimates.

Table 5: ECM estimates

\begin{tabular}{cccccc}
\hline Dependent variable & $\mathrm{B}_{0}$ & $\Delta$ Labour & $\Delta$ Capital & $\Delta$ Tourism & ECT \\
\hline \multirow{2}{*}{$\Delta$ GDP } & $0.001^{* *}$ & $0.528^{* *}$ & $0.077^{* *}$ & $0.038^{* *}$ & $-0.042^{* *}$ \\
& $(2.73)$ & $(9.49)$ & $(8.71)$ & $(2.55)$ & $(-3.19)$ \\
\hline
\end{tabular}

Note: All variables are expressed in natural logarithms. t-tests are presented in parentheses. ${ }^{* *}$ denotes significance at $5 \%$ level.

Empirical results indicate that in the short-run, the semi-elasticity of per capita labour force highly contributes to per capita GDP. On the other hand, per capita tourism and capital have a smaller contribution to economic growth in the short-run. The error correction term depicts the speed of adjustment variables' return to the equilibrium point. It is negative and statistically significant at the $1 \%$ level, confirming the existence of cointegration memory in the estimated variables.

Furthermore, for addressing the cross-sectional dependence ${ }^{4}$ and heterogeneity issues, the Dumitrescu \& Hurlin (2012) panel Granger causality test is also employed. This is a panel causality test based on the individual Wald statistic of Granger non-causality averaged across the cross-section units, taking into consideration the existence of heterogeneity of causal relationships. More specifically, the linear panel regression model is as follows.

$$
y_{i t}=a_{i}+\sum_{j=1}^{J} b_{i}^{j} y_{i, t-j}+\sum_{j=1}^{J} c_{i}^{j} x_{i, t-j}+e_{i, t}
$$

where $y$ is real per capita income and $x$ is the vector-independent variables (labour force, gross fixed capital formation, and tourist arrivals). The null hypothesis tests the noncausal relationship for any of the cross-section units against the alternative hypothesis that causal relationships occur for at least one subgroup of the panel. Thus, rejection of the null hypothesis indicates that $x$ Granger causes $y$ for all $i$ regions. In terms of the aforementioned analysis, Table 6 presents the Granger (Emirmahmutoğlu \& Köse, 2011) causality tests.

3 The set of equations defining the formal model is provided in Appendix A.

${ }^{4}$ All Pesaran (2020) CD tests for cross-dependence across countries reject the null hypothesis for no crossdependence. That means that the natural logarithm of GDP per capita (CD-test 9.558***), labour force (CD-test $\left.14.516^{* * *}\right)$, gross fixed capital formation (CD-test 13.84***), and tourism (CD-test 24.203***) are cross-sectionally dependent. That result also means that Pesaran Panel Unit Root Test with crosssectional and first-difference mean should also be estimated. These tests give very similar results to the first-generation unit tests results as presented in Appendix B. 
Table 6: Pairwise Dumitrescu-Hurlin Panel Causality Tests

\begin{tabular}{|c|c|c|c|c|c|c|}
\hline \multirow{4}{*}{ W-tests (lag order 1 ) } & \multicolumn{2}{|c|}{ Labour \& GDP } & \multicolumn{2}{|c|}{ Capital \& GDP } & \multicolumn{2}{|c|}{ Tourism \& GDP } \\
\hline & Wald & Decision & Wald & Decision & Wald & Decision \\
\hline & $2.970^{* *}$ & $\Longleftrightarrow$ & $2.730^{* *}$ & $\Longrightarrow$ & $2.742^{* *}$ & $\Longleftrightarrow$ \\
\hline & $6.465^{* *}$ & & 1.611 & & $1.190^{* *}$ & \\
\hline
\end{tabular}

Note: Null hypothesis states that $\mathrm{X}_{1}$ does not Granger cause $\mathrm{X}_{2}$ and the alternative hypothesis states that $\mathrm{X}_{1}$ does Granger cause $\mathrm{X}_{2}$. ${ }^{* *}$ denotes significance at $5 \%$ level.

As shown, there is a two-way (bidirectional) causality between labour and GDP and tourism and per capita GDP, confirming the feedback hypothesis between tourism and economic growth in the Mediterranean area. On the other hand, it seems that there is a one-way causality running from capital to per capita GDP, meaning that capital could be a weakly exogenous variable.

\subsection{PVAR Analysis}

To better understand the dynamic interaction of the four endogenous variables of interest, we adopt a recent multivariate econometric technique, PVAR analysis that is proposed in Sims (1980) and enables to deal with the difference among units (Satrovic \& Muslija, 2019). More specifically, we consider a four-variate homogeneous panel VAR of order $p$ using a GMM estimator to eliminate country-fixed and time effects. This panel is represented by the following system of linear equations.

$$
y_{i t}=a_{0}+a(L) y_{i t}+u_{i}+\delta_{i t}+e_{i t}
$$

where $y_{i t}$ is a 4 -dependent variable vector (GDP, Labour, Capital, Tourism); $a_{0}$ is the constant vector; $a(L)$ represents the matrix polynomial in the lag operator $\left(a_{1} L^{1}+a_{2} L^{2}+\right.$ $\left.\ldots+a_{p} L^{p}\right) ; u_{i}$ indicates the country-specific fixed effects accounting for the time-invariant individual effects; $\delta_{i t}$ indicates the country-time effects; and $e_{i t}$ denotes the error term. The GMM estimator used in PVAR suffers from weak instrument problems when the variables being modelled are near the unit root. Thus, as it is shown previously that all variables are $\mathrm{I}(1)$, the rest of the analysis is estimated using growth rates of these variables.

As the first step, we use selection-order statistics, identifying the optimal moments and lag order. Table 7 presents results from the estimated-order panel VAR models using the first four lags of the endogenous variables as instruments.

Table 7: Lag Order

\begin{tabular}{cccccc}
\hline Lags & CD & J & MBIC & MAIC & MQIC \\
\hline 1 & 0.53 & 80.974 & -200.2 & -15.03 & -88.73 \\
2 & 0.65 & 53.195 & -134.26 & -10.81 & -59.94 \\
3 & 0.71 & 41.769 & -51.957 & 9.77 & -14.8 \\
\hline
\end{tabular}

Based on Andrews \& Lu (2001) approach, the first-order panel VAR is the preferred model because it has the smallest MBIC, MAIC, and MQIC statistics. However, we should be cautious, as the non-minimization of Hansen's J statistic could indicate possible misspecification in the model. However, as stated previously, we mitigate this issue by using the growth rates of the employed variables in the panel VAR model instead of the variables in levels. 
Table 8: Results of the PVAR Model

\begin{tabular}{lcccc}
\hline Response of & Lag of GDP & Lag of Labour & Lag of Capital & Lag of Tourism \\
\hline \multirow{2}{*}{ Response to GDP } & $0.281^{* *}$ & $0.391^{* *}$ & $0.022^{*}$ & $0.028^{* *}$ \\
& $(3.74)$ & $(4.54)$ & $(1.51)$ & $(1.85)$ \\
\hline Note: All variables are expressed in growth rate of per capita values. ${ }^{* *}$ and ${ }^{*}$ denote \\
statistical significance at 5\% and 10\%, respectively.
\end{tabular}

The results, as expected, show that the first lag of labour, capital, and tourism growth have positive effects on current growth in per capita GDP, Table 8. The coefficient of lag of labour force growth is estimated equal to 0.39 , while the coefficients of capital and tourism growth (0.22 and 0.28 , respectively) are smaller confirming the higher significance of labour in this specific area of countries. In addition, this result is of high interest as it confirms that an augmented neo-classical growth model with the tourism sector is a dynamic process for Southern Europe economies. In other words, it can be said that present results provide valuable insights in assisting the economic growth of Mediterranean countries by improving the structure of its economy with respect to the neo-classical drivers, labour and capital, as well as tourism sector simultaneously that is proved from the extended model.

Econometrically, another important characteristic of the estimated model is its stability, implying that the panel VAR is invertible and has an infinite-order vector moving-average (VMA) representation. Figure 2 confirms that the model is stable, as the roots of the companion matrix are all inside the unit circle. This indicates that the interpretation of the estimated impulse-response functions (IRFs) and forecast-error variance decompositions (FEVDs) is valid (Abrigo \& Love, 2016).

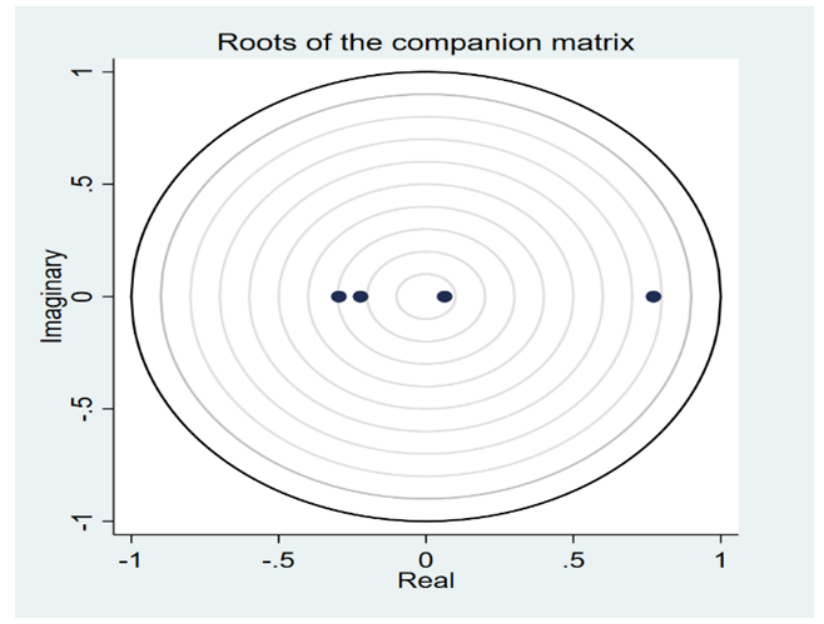

Figure 2: Stability Test

As the panel VAR model is stable, we can assess FEVDs and IRFs. Orthogonalized impulse response functions and variance decompositions are affected depending on the order of the endogenous variables in the decomposition. ${ }^{5}$ Specifically, the ordering constrains the

\footnotetext{
${ }^{5}$ Following the common procedure, the ordering of variables is selected as follows: an exogenous variable would impact first on an endogenous variable.
} 
timing of the responses, as shocks on variables that come first in the ordering will affect subsequent variables contemporaneously, while shocks on variables that come later in the ordering will affect only the previous variables with a lag of one period (Abrigo \& Love, 2016). Table 9 shows the VDCs of the estimated panel VAR model.

Table 9: VDCs for GDP, Labour, Capital, Tourism

\begin{tabular}{ccccc}
\hline $\begin{array}{c}\text { Response variable and } \\
\text { forecast horizon }\end{array}$ & \multicolumn{4}{c}{ Impulse variance } \\
\hline 2 & GDP & Labour & Capital & Tourism \\
5 & 0.938 & 0.047 & 0.009 & 0.006 \\
10 & 0.88 & 0.105 & 0.01 & 0.007 \\
& 0.868 & 0.117 & 0.01 & 0.007 \\
\hline
\end{tabular}

Variance decompositions present the percentage of the forecast error variance in the growth of per capita GDP that is explained in the shock in growth rates of per capita tourism, capital, and labour. The total effect is accumulated over five and ten quarters. Around $12 \%$ of per capita GDP growth forecast error variance is explained by the growth of per capita labour. On the other hand, only a small part, around $2 \%$ of the variation in per capita GDP growth, is explained by capital and tourism. That result does also confirm the key role labour force plays for South Europe economic performance.

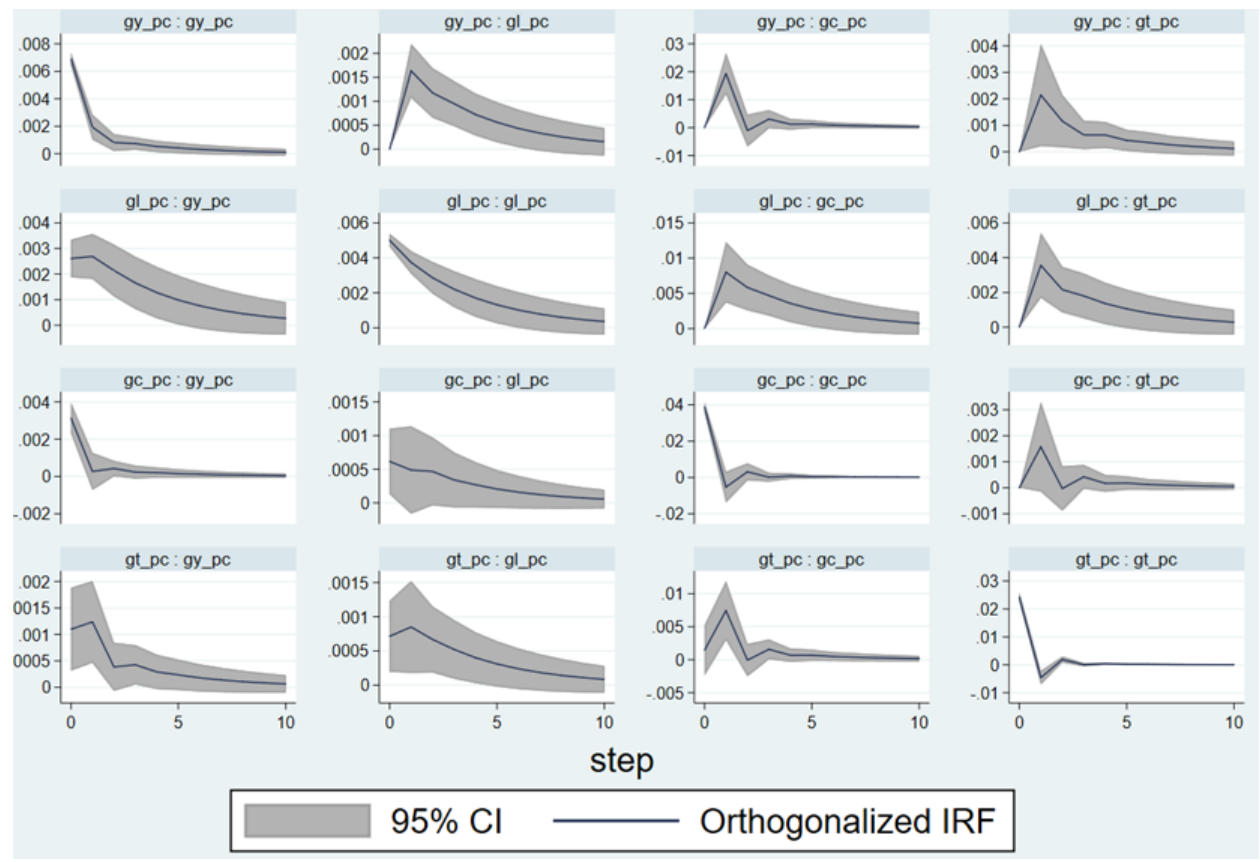

Figure 3: Impulse-Response Functions

In terms of orthogonalized IRFs, following the theoretical exposition by Holtz-Eakin et al. (1988), we also report the impulse response functions when one standard deviation shock is given. Figure 3 shows the IRFs, while the $5 \%$ error bands are generated by Monte Carlo simulation with 200 repetitions. 
From the first column, the effects of one standard deviation shock in all variables on the growth rate of per capita GDP are positive. The magnitude of the effect is smaller for tourism and capital but higher for growth in per capita labour. More specifically, a temporary shock in the growth rate of per capita labour by one standard deviation lasts around five quarters, while shocks in the growth rates of per capita capital and tourism persist only around two or three quarters; then capital and tourism innovations sharply decrease and are very close to zero for the third quarter and become insignificant. On the other hand, looking to the other way around, the response of the per capita GDP growth rate to labour, capital, and tourism seems to have similar results, indicating that temporary and unexpected shocks in tourism and capital might have a small or even insignificant impact on economic performance. However, this is not the case when speaking for the long-run, as found in the previous section.

\section{Concluding Remarks}

The present study augments the empirical research on the relationship between economic growth and tourism using panel data for five Southern European economies over the period 2000Q1-2018Q4. The results from the panel cointegration analysis reveal that there is a long-run equilibrium relationship between economic growth, gross fixed capital formation, labour, and tourist arrivals in per capita terms. More specifically, this relationship shows that a $1 \%$ increase in labour force percent increases real per capita GDP by $0.34 \%$; a $1 \%$ increase in capital formation per capita increases real per capita GDP by $0.23 \%$, and a $1 \%$ increase in tourist arrivals per capita increases real per capita GDP by $0.24 \%$. Proceeding to the short-run relationship, using Granger causality, we estimate that a bidirectional relationship exists between GDP and labour force and tourism, but a one-way relationship between capital and economic growth is confirmed. This shows that capital can be considered as a weakly exogenous variable for our analysis. From the PVAR analysis, it is validated that GDP growth is also affected positively by growth in per capita labour, physical capital and tourism. However, it is worth noting that temporary shocks in labour force have a strong positive direct effect on the growth in per capita real GDP, whereas tourism and capital innovations have a lower short-run effect. These combined results reveal that the period of the shock matters; in the long-run, permanent increases in labour, capital, and the tourism sector lead to higher economic growth, while its effects are smaller when analysing short-run and non-anticipated shocks between the variables.

From the point of view of policy implications, the empirical results restate the economic benefits associated with such government policies as promoting tourism competitiveness. Alternatively, we can indicate that the validity of the bidirectional relationship between tourism and economic growth is consistent with the fact that economies could gain by boosting tourism activity. However, this result should not be generalised. Tourism is a highly volatile parameter and can easily change its dynamic structure. New competitive destinations or a kind of crisis can reduce their benefits within economies. The recent global financial crisis and the current COVID-19 pandemic crisis are two very obvious examples. Economic forecasts from several international institutions indicate that economies that are mainly based on tourism will have dramatic negative effects on its economic performance. That also means that governments and policymakers should avoid focusing on one driver of economic growth, such as tourism, as capital and mainly labour seem to be more stable 
drivers of economic growth. Northern European countries with a higher quality of working conditions and physical capital enjoy higher economic growth and higher standards of living than other economies that based its economic performance on the tourism sector. To sum up, it is confirmed that tourism is a key parameter for enjoying higher economic growth, but labour and capital need to be increased as well.

Despite the potential contribution of the present study, there are some limitations. Due to data constraints, our examined sample covers the period after 2000. In addition, this study focuses solely on the per capita GDP path, while future studies could use data for several economic, social, or environmental components such as private consumption, quality of life, or environmental degradation. In other words, tourism is also confirmed as an important contributor to economic growth, but more results for its impact on economic development are needed. Also, non-linear cointegration panel data methodologies could be applied to further address new econometric thoughts.

\section{References}

Abrigo, M. R., \& Love, I. (2016). Estimation of Panel Vector Autoregression in Stata. The Stata Journal, 16(3), 778-804. doi:10.1177/1536867X1601600314

Adnan Hye, Q. M., \& Ali Khan, R. E. (2013). Tourism-led Growth Hypothesis: A Case Study of Pakistan. Asia Pacific Journal of Tourism Research, 18(4), 303-13. doi:10.1080/10941665.2012.658412

Amir, A. F., Ghapar, A. A., Jamal, S. A., \& Ahmad, K. N. (2015). Sustainable Tourism Development: A Study on Community Resilience for Rural Tourism in Malaysia. Procedia - Social and Behavioral Sciences, 168, 116-22. doi:10.1016/j.sbspro.2014.10.217

Andraz, J. M., \& Rodrigues, P. M. M. (2016). Monitoring Tourism Flows and Destination Management: Empirical Evidence for Portugal. Tourism Management, 56, 1-7. doi:10.1016/j.tourman.2016.03.019

Andrews, D. W., \& Lu, B. (2001). Consistent Model and Moment Selection Procedures for GMM Estimation with Application to Dynamic Panel Data Models. Journal of Econometrics, 101(1), 123-64. doi:10.1016/S0304-4076(00)00077-4

Antonakakis, N., Dragouni, M., Eeckels, B., \& Filis, G. (2019). The Tourism and Economic Growth Enigma: Examining an Ambiguous Relationship through Multiple Prisms. Journal of Travel Research, 58(1), 3-24. doi:10.1177/0047287517744671

Apergis, N., \& Payne, J. E. (2012). Tourism and Growth in the Caribbean - Evidence from a Panel Error Correction Model. Tourism Economics, 18(2), 449-456. doi:10.5367/te.2012.0119

Ballı, E., Sigeze, C., Manga, M., Birdir, S., \& Birdir, K. (2019). The Relationship between Tourism, $\mathrm{CO}_{2}$ Emissions and Economic Growth: A Case of Mediterranean Countries. Asia Pacific Journal of Tourism Research, 219-32. doi:10.1080/10941665.2018.1557717

Banerjee, O., Cicowiez, M., \& Cotta, J. (2016). Economics of Tourism Investment in Data Scarce Countries. Annals of Tourism Research, 60(C), 115-38. doi:10.1016/j.annals.2016.06. 
Bojanic, D. C., \& Lo, M. (2016). A Comparison of the Moderating Effect of Tourism Reliance on the Economic Development for Islands and Other Countries. Tourism Management, 53(C), 207-14. doi:10.1016/j.tourman.2015.10

Breitung, J. (2001). The Local Power of Some Unit Root Tests for Panel Data. In B. H. Baltagi, T. B. Fomby, \& R. Carter Hill (Eds.), Nonstationary Panels, Panel Cointegration, and Dynamic Panels (Advances in Econometrics) (Vol. 15, pp. 161-77). Emerald Group Publishing, Bingley. doi:10.1016/S0731-9053(00)15006-6

Brida, J. G., Cortes-Jimenez, I., \& Pulina, M. (2016). Has the Tourism-led Growth Hypothesis been Validated? A Literature Review. Current Issues in Tourism, 19(5), 394-430. doi:10.1080/13683500.2013.868414

Chen, C.-F., \& Chiou-Weib, S. Z. (2009). Tourism Expansion, Tourism Uncertainty and Economic Growth: New Evidence from Taiwan and Korea. Tourism Management, 30(6), 812-18. doi:10.1016/j.tourman.2008.12.013

Choi, I. (2001). Unit Root Tests for Panel Data. Journal of International Money and Finance, 20(2), 249-72. doi:10.1016/S0261-5606(00)00048-6

Cortes-Jimenez, I., \& Pulina, M. (2010). Inbound Tourism and Long-run Economic Growth. Current Issues in Tourism, 13(1), 61-74. doi:10.1080/13683500802684411

De Vita, G., \& Kyaw, K. S. (2016). Tourism Development and Growth. Annals of Tourism Research, 60(C), 23-26. doi:10.1016/j.annals.2016.05.011

Dritsakis, N. (2004). Tourism as a Long-Run Economic Growth Factor: An Empirical Investigation for Greece Using Causality Analysis. Tourism Economics, 10(3), 305-16. doi:10.5367/0000000041895094

Dumitrescu, E.-I., \& Hurlin, C. (2012). Testing for Granger Non-causality in Heterogeneous Panels. Economic Modelling, 29(4), 1450-60. doi:10.1016/j.econmod.2012.02.014

Emirmahmutoğlu, F., \& Köse, N. (2011). Testing for Granger Causality in Heterogeneous Mixed Panels. Economic Modelling, 28(3), 870-76. doi:10.1016/j.econmod.2010.10.018

Engle, R. F., \& Granger, C. W. J. (1987). Co-Integration and Error Correction: Representation, Estimation, and Testing. Econometrica, 55(2), 251-76. doi:10.2307/1913236

Eugenio-Martín, J. L., Morales, N. M., \& Scarpa, R. (2004). Tourism and Economic Growth in Latin American Countries: A Panel Data Approach (Working Papers No. 26). Fondazione Eni Enrico Mattei (FEEM).

European Commission. (2020). Autumn 2020 Economic Forecast (Institutional paper No. 136).

Eyüboğlu, S., \& Eyüboğlu, K. (2020). Tourism Development and Economic Growth: An Asymmetric Panel Causality Test. Current Issues in Tourism, 23(6), 659-65. doi:10.1080/13683500.2019.1588863

Fahimi, A., Akadiri, S. S., Seraj, M., \& Akadiri, A. C. (2018). Testing the Role of Tourism and Human Capital Development in Economic Growth. A Panel Causality Study of Micro States. Tourism Management Perspectives, 28, 62-70. doi:10.1016/j.tmp.2018.08.004

Gao, J., Xu, W., \& Zhang, L. (2019). Tourism, Economic Growth, and Tourism-induced EKC Hypothesis: Evidence from the Mediterranean Region. Empirical Economics. doi:10.1007/s00181-019-01787-1 
Hadri, K. (2000). Testing for Stationarity in Heterogeneous Panel Data. The Econometrics Journal, 3(2), 148-61. doi:10.1111/1368-423X.00043

Holtz-Eakin, D., Newey, W., \& Rosen, H. S. (1988). Estimating Vector Autoregressions with Panel Data. Econometrica, 56(6), 1371-95. doi:10.2307/1913103

Holzner, M. (2011). Tourism and Economic Development: The Beach Disease? Tourism Management, 32(4), 922-33. doi:10.1016/j.tourman.2010.08.007

Im, K. S., Pesaran, M. H., \& Shin, Y. (2003). Testing for Unit Roots in Heterogeneous Panels. Journal of Econometrics, 115(1), 53-74. doi:10.1016/S0304-4076(03)00092-7

Kao, C. (1999). Spurious Regression and Residual-based Tests for Cointegration in Panel Data. Journal of Econometrics, 90(1), 1-44. doi:10.1016/S0304-4076(98)00023-2

Khan, A., Bibi, S., Lorenzo, A., Lyu, J., \& Babar, Z. U. (2020). Tourism and Development in Developing Economies: A Policy Implication Perspective. Sustainability, 12(4), 1618. doi:10.3390/su12041618

Kostakis, I., Lolos, S., \& Sardianou, E. (2017). Foreign Direct Investment and Environmental Degradation: Further Evidence from Brazil and Singapore. Journal of Environmental Management and Tourism, 8(1), 45-59. doi:10.14505//jemt.v8.1(17).04.

Kostakis, I., \& Theodoropoulou, E. (2017). Spatial Analysis of the Nexus Between Tourism-Human Capital-Economic Growth: Evidence for the Period 2000-2014 Among NUTS-II Southern European Regions. Tourism Economics, 23(7), 1523-34. doi:10.1177/1354816617692473

Kumar, R., \& Stauvermann, P. J. (2016). Dataset for an Analysis of Tourism and Economic Growth: A Study of Sri Lanka. Data in Brief, 8, 723-25. doi:10.1016/j.dib.2016.06.066

Lee, C.-C., \& Chang, C.-P. (2008). Tourism Development and Economic Growth: A Closer Look at Panels. Tourism Management, 29(1), 180-92. doi:10.1016/j.tourman.2007.02.013

Lee, J. W., \& Brahmasrene, T. (2013). Investigating the Influence of Tourism on Economic Growth and Carbon Emissions: Evidence from Panel Analysis of the European Union. Tourism Management, 38, 69-76. doi:10.1016/j.tourman.2013.02.016

Levin, A., Lin, C.-F., \& Chu, C.-S. J. (2002). Unit Root Tests in Panel Data: Asymptotic and Finite-sample Properties. Journal of Econometrics, 108(1), 1-24. doi:10.1016/S03044076(01)00098-7

Liang, Z.-X., \& Hui, T.-K. (2016). Residents' Quality of Life and Attitudes Toward Tourism Development in China. Tourism Management, 57, 56-67. doi:10.1016/j.tourman.2016.05.001

Matias, A., Nijkamp, P., \& Sarmento, M. (2011). Impact of Tourism. In A. Matias, P. Nijkamp, \& M. Sarmento (Eds.), Tourism Economics: Impact Analysis (pp. 1-8). Physica-Verlag Heidelberg. doi:10.1007/978-3-7908-2725-5

Morakabati, Y., Fletcher, J., \& Prideaux, B. (2012). Tourism Development in a Difficult Environment: A Study of Consumer Attitudes, Travel Risk Perceptions and the Termination of Demand. Tourism Economics, 18(5), 953-69. doi:10.5367/te.2012.0162

Muslija, A., Satrovic, E., \& Erbaş, C. U. (2017). Panel Analysis of Tourism-economic Growth Nexus. Uluslararası Ekonomik Araştırmalar Dergisi, 3(4), 535-45. 
Nunkoo, R., Seetanah, B., Jaffur, Z., Moraghen, P., \& Sannassee, R. (2020). Tourism and Economic Growth: A Meta-regression Analysis. Journal of Travel Research, 59(3), 404-23. doi:10.1177/0047287519844833

Oh, C.-O. (2005). The Contribution of Tourism Development to Economic Growth in the Korean Economy. Tourism Management, 26(1), 39-44. doi:10.1016/j.tourman.2003.09.014

Paci, R., \& Marrocu, E. (2014). Tourism and Regional Growth in Europe. Papers in Regional Science, 93(S1), S25-S50. doi:10.1111/pirs.12085

Payne, J. E., \& Mervar, A. (2010). Research Note: The Tourism-Growth Nexus in Croatia. Tourism Economics, 16(4), 1089-94. doi:10.5367/te.2010.0014

Pedroni, P. (1999). Critical Values for Cointegration Tests in Heterogeneous Panels with Multiple Regressors. Oxford Bulletin of Economics and Statistics, 61(S1), 653-70. doi:10.1111/1468-0084.0610s1653

Pedroni, P. (2004). Panel Cointegration: Asymptotic and Finite Sample Properties of Pooled Time Series Tests with an Application to the PPP Hypothesis. Econometric Theory, 20(3), 597-625. doi:10.1017/S0266466604203073

Pesaran, M. H. (2020). General Diagnostic Tests for Cross-sectional Dependence in Panels. Empirical Economics. doi:10.1007/s00181-020-01875-7

Pulido-Fernández, J., \& Cárdenas-García, P. (2020). Analyzing the Bidirectional Relationship between Tourism Growth and Economic Development. Journal of Travel Research. doi:10.1177/0047287520922316

Pulido Fernández, J. I., \& Sánchez Rivero, M. (2010). Competitividad versus Crecimiento en Destinos Turísticos. Un Análisis Mediante Técnicas Multivariantes. Cuadernos de Economía, 33(91), 159-81. doi:10.1016/S0210-0266(10)70061-3

Satrovic, E., \& Muslija, A. (2019). The Empirical Evidence on Tourism-urbanization- $\mathrm{CO}_{2}$ Emissions Nexus. Advances in Hospitality and Tourism Research (AHTR), 7(1), 85-105. doi:10.30519/ahtr.484287

Schubert, S., Brida, J., \& Risso, W. (2011). The Impacts of International Tourism Demand on Economic Growth of Small Economies Dependent on Tourism. Tourism Management, 32(2), 377-85. doi:10.1016/j.tourman.2010.03.007

Sims, C. (1980). Macroeconomics and Reality. Econometrica, 48(1), 1-48. doi:10.2307/1912017

Soukiazis, E., \& Proenca, S. (2008). Tourism as an Alternative Source of Regional Growth in Portugal: A Panel Data Analysis at NUTS II and III Levels. Portuguese Economic Journal, 7(1), 43-61. doi:10.1007/s10258-007-0022-0

Tang, C., \& Tan, E. (2015). Does Tourism Effectively Stimulate Malaysia's Economic Growth? Tourism Management, 46, 158-63. doi:10.1016/j.tourman.2014.06.020

Tuğcu, C. T. (2014). Tourism and Economic Growth Nexus Revisited: A Panel Causality Analysis for the Case of the Mediterranean Region. Tourism Management, 42, 207-12. doi:10.1016/j.tourman.2013.12.007

Westerlund, J. (2007). Testing for Error Correction in Panel Data. Oxford Bulletin of Economics and Statistics, 69(6), 709-48. doi:10.1111/j.1468-0084.2007.00477.x 
World Travel and Tourism Council. (2020). Global Economic Impact \& Trends 2020. https://wttc.org/Research/Economic-Impact/moduleId/1445/itemId/91/ controller/DownloadRequest/action/QuickDownload.

Zhang, L., \& Gao, J. (2016). Exploring the Effects of International Tourism on China's Economic Growth, Energy Consumption and Environmental Pollution: Evidence from a Regional Panel Analysis. Renewable and Sustainable Energy Reviews, 53, 225-34. doi:10.1016/j.rser.2015.08.040

\section{Appendices}

\section{Appendix A: Formal Model}

$$
\begin{gathered}
\operatorname{GDP}_{i t}=a_{1}+\sum_{j=1}^{J} b_{i}^{j} \operatorname{GDP}_{(i, t-j)}+\sum_{j=1}^{J} c_{i}^{j} \operatorname{Labour}_{(i, t-j)}+\sum_{j=1}^{J} c_{i}^{j} \operatorname{Capital}_{(i, t-j)}+\sum_{j=1}^{J} c_{i}^{j} \operatorname{Tourism}_{(i, t-j)}+e_{(1, t)} \\
\operatorname{Labour}_{i t}=a_{1}+\sum_{j=1}^{J} b_{i}^{j} \operatorname{Labour}_{(i, t-j)}+\sum_{j=1}^{J} c_{i}^{j} \operatorname{GDP}_{(i, t-j)}+\sum_{j=1}^{J} c_{i}^{j} \operatorname{Capital}_{(i, t-j)}+\sum_{j=1}^{J} c_{i}^{j} \operatorname{Tourism}_{(i, t-j)}+e_{(2, t)} \\
\operatorname{Capital}_{i t}=a_{1}+\sum_{j=1}^{J} b_{i}^{j} \operatorname{Capital}_{(i, t-j)}+\sum_{j=1}^{J} c_{i}^{j} \operatorname{Labour}_{(i, t-j)}+\sum_{j=1}^{J} c_{i}^{j} \operatorname{GDP}_{(i, t-j)}+\sum_{j=1}^{J} c_{i}^{j} \operatorname{Tourism}_{(i, t-j)}+e_{(3, t)} \\
\operatorname{Tourism}_{i t}=a_{1}+\sum_{j=1}^{J} b_{i}^{j} \operatorname{Tourism}_{(i, t-j)}+\sum_{j=1}^{J} c_{i}^{j} \operatorname{Labour}_{(i, t-j)}+\sum_{j=1}^{J} c_{i}^{j} \operatorname{Capital}_{(i, t-j)}+\sum_{j=1}^{J} c_{i}^{j} G D P_{(i, t-j)}+e_{(3, t)}
\end{gathered}
$$

\section{Appendix B: Additional Table}

Table B.1: Pesaran Panel Unit Root Test with Cross-sectional and First-difference Mean

\begin{tabular}{llllllllll}
\hline Tests & Deterministic & GDP & $\Delta$ GDP & Labour & $\Delta$ Labour & Capital & $\Delta$ Capital & Tourism & $\Delta$ Tourism \\
\hline \multirow{2}{*}{ CADF } & C & -0.06 & $-4.120^{* *}$ & $2.709^{* *}$ & $-4.470^{* *}$ & -1.356 & $-5.426^{* *}$ & $-2.909^{* *}$ & $-5.721^{* *}$ \\
& C\&T & -2.25 & $-4.400^{* *}$ & -2.575 & $-4.751^{* *}$ & -1.531 & $-5.546^{* *}$ & $-3.017^{* *}$ & $-5.846^{* *}$ \\
\hline \multirow{2}{*}{ CIPS } & $\mathrm{C}$ & 0.429 & $-5.826^{* *}$ & $-2.959^{* *}$ & $-5.467^{* *}$ & -0.945 & $-6.190^{* *}$ & $-2.756^{* *}$ & $-5.963^{* *}$ \\
& $\mathrm{C} \& \mathrm{~T}$ & -1.36 & $-5.997^{* *}$ & -2.326 & $-5.624^{* *}$ & -0.996 & $-6.405^{* *}$ & $-2.729^{* *}$ & $-6.158^{* *}$ \\
\hline
\end{tabular}

Note: All variables (GDP, Labour, Capital and Tourism) are expressed in their natural logarithms. The Greek letter $\Delta$ denotes the first difference of the variables. C is the constant term, and C\&T denotes constant and trend. The null hypothesis is that all series have a unit root. ${ }^{* *}$ denotes statistical significance at $5 \%$. 